\title{
Operational Scaling-Up use of Larvivorous Fishes and its Impact on Prevalence of Malaria in Mandvi Taluka of District Kutch Gujarat
}

\section{Sarfarazul Haq*}

National Institute of Malaria Research (ICMR), Dwarka, New Delhi-110077, India

Use of larvivorous fish in mosquito control has been well established specially the effectiveness of fishes like Gambusia affinis, Poecilia reticulata and some indigenous fishes in different mosquito breeding habitats [1-4]. However, reports on operational level scaling up or largescale use of fishes are scanty [5-7]. In India, use of larvivorous fishes has become an element in vector control policy of the National Vector Borne Disease Control Programme (NVBDCP). We used a systematic approach of scaling-up of use of the larvivorous fishes in Mandvi taluka (Sub-District), District Kutch, Gujarat in 2008-2009 selected on the basis of high prevalence of malaria during 2007 and suitable ecological conditions for use of larvivorous fishes. We trained the vector control staff in catching of fishes from natural habitats, transportation and release into mosquito breeding habitats and monitoring impact of this intervention on mosquito larval densities and malaria prevalence.

In order to initiate the work in district Kutch meetings with $\mathrm{CDHO}$ and DMO were organized. The Malaria situation in the district was reviewed. Considering the rising trend of malaria in Madvi taluka, it was decided to take up the Mandvi taluka comprising of four PHCs to begin with the scaling-up use of larvivorous fishes. The Medical Officers of all the PHCs were invited for the briefing up of project activities and to extend their cooperation in achieving the targets. The Performa of fish application in different habitats on monthly basis in their PHCs were provided for recording the monthly progress. They were also taken to the field for demonstrations and showing the collection sites of Aphanius fishes on the outskirts of Mandvi city and other natural habitats. The field and other staff at the district, PHCs and Block Health Officer (BHO) level in the district were given necessary training on technical aspects, operational issues such as collection, transportation,

\begin{tabular}{clccccccc}
\hline S.N. & Name of & Village & \multicolumn{7}{c}{ Mosquito breeding habitats } \\
\cline { 3 - 8 } & & $\begin{array}{c}\text { Khet Talavdi } \\
\text { (Farm tanks) }\end{array}$ & Wells & Ponds & Pools & $\begin{array}{c}\text { Riverbed } \\
\text { pools }\end{array}$ & $\begin{array}{c}\text { Check } \\
\text { Dams }\end{array}$ & Others \\
\hline 1 & Godhara & 64 & 4 & 1 & 0 & 1 & 1 & 2 \\
2 & Merau & 41 & 0 & 0 & 0 & 0 & 1 & 0 \\
3 & Bayath & 15 & 2 & 1 & 1 & 1 & 0 & 0 \\
4 & Padampur & 20 & 0 & 0 & 0 & 0 & 1 & 0 \\
5 & Mota Layja & 13 & 1 & 1 & 1 & 1 & 0 & 0 \\
6 & Bhada & 0 & 0 & 3 & 0 & 1 & 0 & 0 \\
7 & Bada & 0 & 0 & 2 & 0 & 0 & 0 & 0 \\
8 & Mapar & 0 & 0 & 1 & 0 & 0 & 0 & 0 \\
9 & Bambhdai & 0 & 0 & 1 & 0 & 0 & 0 & 0 \\
10 & Panchotiya & 0 & 1 & 1 & 0 & 0 & 0 & 0 \\
11 & Jankpur & 10 & 0 & 0 & 0 & 0 & 0 & 0 \\
12 & Bhisara & 3 & 1 & 1 & 0 & 0 & 0 & 0 \\
13 & Shirva & 72 & 5 & 2 & 1 & 0 & 1 & 0 \\
14 & Kathada & 49 & 1 & 3 & 0 & 0 & 0 & 0 \\
15 & NanaLayja & 9 & 0 & 1 & 0 & 0 & 0 & 0 \\
16 & Durgapur & 15 & 1 & 1 & 0 & 1 & 0 & 0 \\
17 & Bharapar & 49 & 0 & 1 & 0 & 1 & 2 & 0 \\
18 & Vada & 15 & 1 & 1 & 0 & 1 & 1 & 0 \\
\hline & Total & 375 & 17 & 21 & 3 & 7 & 7 & 2 \\
\hline
\end{tabular}

Table 1: Mosquito breeding habitats in Godhra PHC of Mandvi Taluka. introduction of the fish in all habitats, precautions during handling of fish and fish density determination etc.

Geographical reconnaissance of mosquito breeding habitats in 18 villages of Godhra PHC (Table 1) was conducted in the month of November, 2008 to have a numerical estimate and type of permanent and most common mosquito breeding habitats in Mandvi Taluka. The main water bodies included 375 man made farm tanks used for irrigation (khet talavdis), 17 wells, 21 village ponds and small weirs (check-dams) across slow rain-fed running streams. Other habitats included household water storage tanks, cattle troughs and river bed pools. In other PHCs of the taluka, similar information was collected by the PHC staff. The data was used for planning fish application in the identified water bodies.

Gambusia affinis was collected from some of the perennial ponds being used as mother hatcheries and Aphanius dispar was collected from the back waters along the coast line of the Mandvi taluka. These fishes were released at a large scale with the collaboration of PHC staff in four PHCs viz. Godhra, Talwana, Darsadi and Gadhsisa of Mandvi Taluka from November, 2008 to March, 2009. Application was made mainly in tanks, wells, ponds and check dams. Overall more than 2.22 million fishes were released in 328 potential mosquito breeding habitats of 48 villages comprising of 176 farm tanks (Khet Talavdi), 14 wells, 31 ponds, 9 pools, 13 check dams and 79 other habitats including very large sized pools made from mining excavations in four PHCs of Mandvi Taluka (Table 2). In the follow up visits carried out after three months, six months and nine months respectively during 2009, fishes were found surviving and multiplying in most of the habitats.

The impact of fish on larval densities was monitored before and after fish application in the 22 sentinel tanks and 5 wells through standard methods. Mosquito density was measured with the help of standard 30 $\mathrm{ml}$ dipper in tanks and 5 litter iron bucket in wells. Ten dips were taken from different corners of each tank and density of III and IV instars larvae per dip was calculated by dividing the total number of larvae by total numbers of dips. In wells average density of III and IV instars larvae of three dips was calculated.

The average anopheline larval densities in the tanks and wells sharply declined after fish application. The average larval density of all instars declined from 11.29 per dip (Pre-fish application) in November 2008 to 0.01 per dip (post-fish application) in February, 2009 and subsequently 0.009 in September, 2009. Similar results were obtained in

*Corresponding author: Sarfarazul Haq, National Institute of Malaria Research (ICMR), Dwarka, New Delhi-110077, India, E-mail: sarfaraz_55@'rediffmail.com

Received May21, 2013; Accepted June 11, 2013; Published june 13, 2013

Citation: Haq S (2013) Operational Scaling-Up use of Larvivorous Fishes and its Impact on Prevalence of Malaria in Mandvi Taluka of District Kutch Gujarat. Trop Dis 1: 108. doi:10.4172/2329-891X.1000108

Copyright: (C) 2013 Haq S. This is an open-access article distributed under the terms of the Creative Commons Attribution License, which permits unrestricted use, distribution, and reproduction in any medium, provided the original author and source are credited. 
case of wells. A highly significant impact $(\mathrm{P}<0.001)$ on larval densities of the vector species A. culicifacies in tanks and wells was recorded during the post fish application period in district Kolar, Karnataka, however the impact on $A$. fluviatilis $(\mathrm{P}<0.05)$ was insignificant may be because of the breeding preference of this species in streams where larvivorous fishes were not equally effective [5].

The impact of fish on malaria prevalence was also monitored in 2009 using the data available through routine surveillance from the four PHCs. There was a decline in slide positivity rate and malaria cases were less in 2009 as compared to that of 2008 during the corresponding months (Figure 1). In a six years study (1993-1999) on the use of larvivorous fishes and its impact on malaria incidence in Kolar district, Karnataka a sharp reduction in malaria cases and API (cases per 1000 population) came down to a very low level in 1999 as compared to the

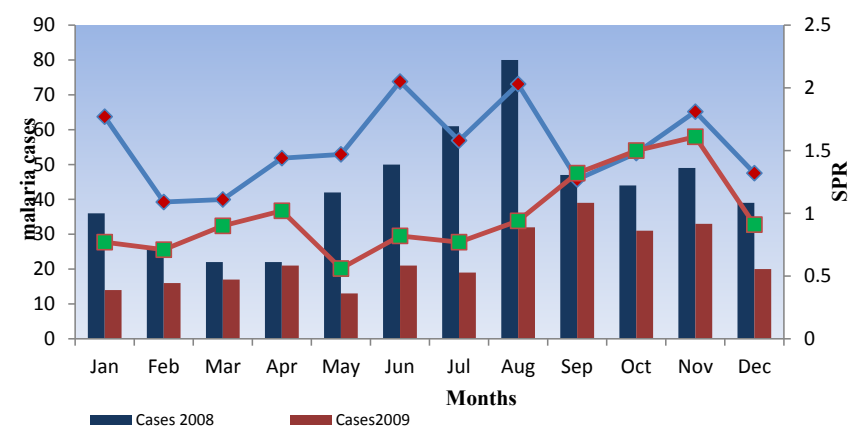

Figure 1: Impact of larvivorous fishes on malaria prevalence in four PHCs of Mandvi taluka (Sub-District).

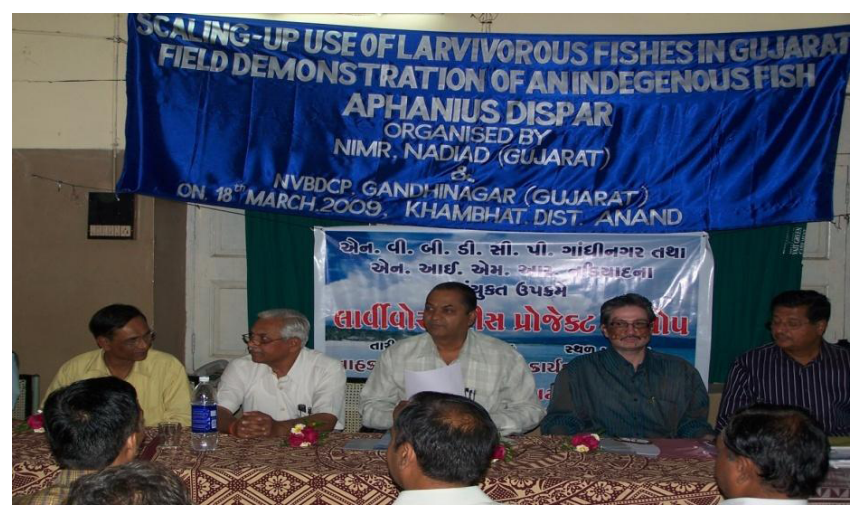

Figure 2: Workshop on scaling up use of larvivorous fishes in collaboration with the Commissionerate of Health, Gujarat, India. base year 1993 (reduction 99.8\%, P<0.001) [5]. Again in Karnataka in another study, Poecilia reticulata fish introduced into all mosquito breeding habitats in some villages brought down zero vector density in Puram village and no malaria cases were detected in the three villages after one year release of fish [6].

Larvivorous fish may prove to be a good option to insecticides in vector control where breeding habitats of malaria vectors are confined during most part of the year. But, this can be achieved only after following a systematic approach towards developing an operational larvivorous fish network and infrastructure in the form of adequate fish resources, and a fully equipped and trained staff. Experience of the development of larvivorous fish network for mosquito control in Ahmedabad city demonstrated the feasibility of using larvivorous fishes and proved that this can play an important role in mosquito control in urban areas provided a systematic and planned approach is applied [7]. Gambusia fishes are an integral part of the integrated pest management strategies employed by mosquito control agencies in the New Jersey.

During the recent past there has been a renewed interest in Gambusia, and they are probably stocked in more areas throughout NJ than ever before as they have been found very effective in woodland pools, mine pits, storm water management facilities, ornamental pools, abandoned swimming pools, ditches, brackish marshes, and freshwater swamps [8]. This strategy may be helpful in controlling the re-emergence of mosquito borne diseases, particularly in urban areas and will reduce the dependence on insecticides.

In an effort to popularize use of larvivorous fishes at programmatic level in Gujarat a field demonstration and workshop on the use of larvivorous fishes was organized jointly by NIMR and NVBDCP in Khambhat taluka of Anand district on $18^{\text {th }}$ March, 2009 (Figure 2). Besides the scientists of NIMR, the Joint Director, State entomologist, CDHO, Epidemic Medical Officer, Asst. Entomologists, Dist. Malaria Officer, Block Health Officer, Medical Officers and other field staff attended the workshop. All participants were taken to the field for witnessing (Figure 3) the large scale availability of Aphanius fish. In the field collection and packaging of fishes in oxygen supplied polythene begs was demonstrated. Fishes were supplied to DMOs of different districts for propagation in their respective areas. The use of larvivorous fishes is in full swing to cover the entire states of Gujarat and Karnataka.

In conclusion, the use of larvivorous fish has been found an effective and environmental friendly and sustainable selective vector control method. The results of the present study indicate that the use of larvivorous fishes can be a great help to state vector control programme especially in coastal parts of Gujarat where Aphanius fish is also available in large numbers. There is a need to strengthen the vector control programme and capacity building of the staff engaged in vector

\begin{tabular}{|c|c|c|c|c|c|c|c|c|c|c|c|c|c|}
\hline \multirow{3}{*}{$\mathrm{PHC}$} & \multirow{3}{*}{ Village } & \multicolumn{12}{|c|}{ Mosquito breeding habitats } \\
\hline & & \multicolumn{2}{|c|}{$\begin{array}{l}\text { Khet Talavadi } \\
\text { (Farm tanks) }\end{array}$} & \multicolumn{2}{|c|}{ Wells } & \multicolumn{2}{|c|}{ Ponds } & \multicolumn{2}{|c|}{ Pools } & \multicolumn{2}{|c|}{ Check dams } & \multicolumn{2}{|c|}{ Others } \\
\hline & & No. & Fish & No. & Fish & No. & Fish & No. & Fish & No. & Fish & No. & Fish \\
\hline Godhara & 14 & 97 & 396590 & 5 & 2800 & 9 & 30000 & 2 & 2000 & 1 & 15000 & 2 & 2000 \\
\hline Talwana & 13 & 64 & 327500 & 2 & 450 & 5 & 57000 & - & - & - & - & 22 & 5700 \\
\hline Darsadi & 11 & 14 & 79800 & 5 & 550 & 11 & 113000 & 7 & 58000 & 12 & 126000 & 48 & 759200 \\
\hline Gadhsisa & 08 & 01 & 100000 & 1 & 200 & 6 & 98000 & - & - & - & - & 7 & 50000 \\
\hline Total & 46 & 176 & 903890 & 14 & 4000 & 31 & 298000 & 9 & 60000 & 13 & 141000 & 79 & 816900 \\
\hline
\end{tabular}

Total fish released:2223790 


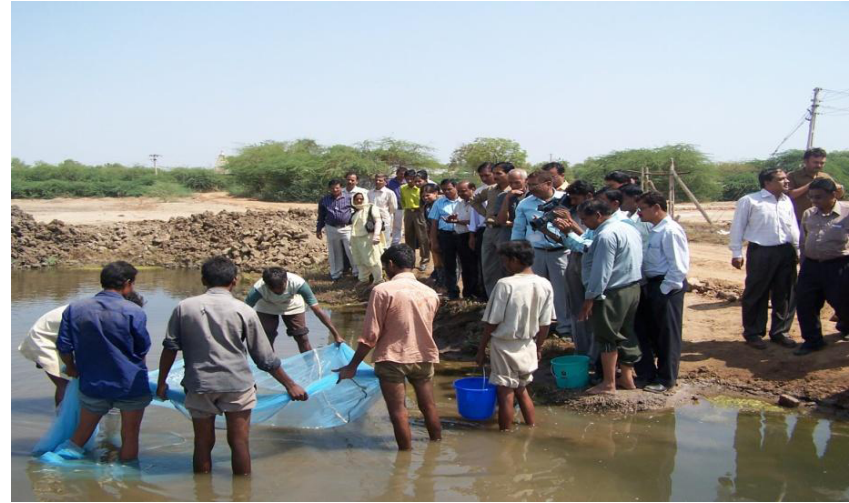

Figure 3: Field demonstration to District Malaria Officers (DMOs) and PHC Medical Officers (MOs) on the occurrence and availability of Aphanius dispar fish in Khambhat, District Anand.

control by providing the necessary trainings on technical aspects, operational issues such as fish identification, collection, transportation, introduction of the fish in all mosquito breeding habitats, precautions during handling and fish density determination etc. Although the use of larvivorous fishes in the malaria control programme has been taken up on operational scale with variable performance levels but large-scale operational use of larvivorous fish for vector control still remains under exploited at the national level and there is an urgent need to set up a national level research and training facility.

\section{Acknowledgements}

The authors acknowledge the financial support provided by NVBDCP, Comissionerate of Health, Gandhinagar, Gujarat and the Director, NIMR for providing Institutional facilities, District Malaria Officer, District Kutch, Medical officers of Mandvi Taluka PHCs and field staff for active cooperation and the staff of NIMR, Field Station, Nadiad for their assistance in the field work. This paper bears the NIMR publication screening committee approval no. 030/2012.

\section{References}

1. Chandra G, Bhattacharjee I, Chatterjee SN, Ghosh A (2008) Mosquito control by larvivorous fish. Indian J Med Res 127: 13-27.

2. Ghosh SK, Chakaravarthy P, Panch SR, Krishnappa P, Tiwari S, et al. (2011) Comparative efficacy of two poeciliid fish in indoor cement tanks against chikungunya vector Aedes aegypti in villages in Karnataka, India. BMC Public Health 11: 599 .

3. Haq S, Prasad H, Prasad RN, Sharma T (1993) Availability and utility of local fishes of Shahjahanpur for mosquito control. Indian J Malariol 30: 1-8.

4. Fletcher M, Teklehaimanot A, Yemane G (1992) Control of mosquito larvae in the port city of Assab by an indigenous larvivorous fish, Aphanius dispar. Acta Trop 52: 155-166.

5. Ghosh SK, Tiwari SN, Kulshreshtha AK, Sathyanarayan TS, Sampat TRR (2002) Control of malaria transmission using larvivorous fishes. In trends in Malaria and Vaccine Research- the Current Indian Scenario. Eds. D. Raghunath and R. Nayak (Tata McGraw-Hill Publishing Company Ltd., New Delhi) 154-158.

6. Ghosh SK, Tiwari SN, Sathyanarayan TS, Sampath TR, Sharma VP, et al (2005) Larvivorous fish in wells target the malaria vector sibling species of the Anopheles culicifacies complex in villages in Karnataka, India. Trans R Soc Trop Med Hyg 99: 101-105.

7. Haq S, Yadav RS, Kohli, VK (2003) Developing larvivorous fish network for mosquito in urban areas: a case study. ICMR Bulletin 33: 69-73.

8. Duryea R, Donnelly J, Guthrie D, O’Malley C, Romanowski M, et al. (1996) Gambusia affinis effectiveness in new Jersey mosquito control. Proceedings of the Eighty-Third Annual Meeting of the New Jersey Mosquito Control Association, Inc. 95-102. 